\title{
The Conceptual and Hypothetical Model of Interactive Blended Problem Based Learning
}

\author{
Hansi Effendi ${ }^{1}$, Yeka Hendriyani ${ }^{2}$ \\ 1 Jurusan Teknik Elektro, Universitas Negeri Padang, Kota Padang, Indonesia \\ 2Jurusan Teknik Elektronika, Universitas Negeri Padang, Kota Padang, Indonesia \\ e-mail: hans_79@ft.unp.ac.id, yekahendriyani@ft.unp.ac.id
}

\begin{abstract}
This article discusses the results of research on the development of conceptual models and hypothetical models of Interactive Blended Problem Based Learning (IBPBL) in Programming Language subjects for Electrical Engineering students at Universitas Negeri Padang. This model is a blended learning model that combines face-to-face learning in class and Moodle-based online learning with problem-based learning syntax in the field of Electrical Engineering. The research was carried out in three stages: (1) literature review, (2) formulation of the conceptual model, and (3) formulation of the hypothetical model. The IBPBL conceptual models consist of: (1) philosophical components: pragmatism; (2) theoretical components: cognitivism, behaviorism, constructivism, and connectivism; (3) methodological components: problem-based learning; and (4) technical components: problemsolving, cooperation, critical thinking, innovative, creative and systematic. The hypothetical model is based on students' ability to solve problems critically, creatively, collaboratively, systematically by utilizing the various advantages possessed by face-to-face and online learning in Programming Language courses. Model validation is done using expert judgment. The expert assessment assessed the IBPBL model in three aspects, namely: (1) component sufficiency, (2) content, and (3) ease of implementation.
\end{abstract}

Keywords: Instructional Model Development; Blended Learning; Problem-Based Learning; Interactive; Programming Language

\section{Introduction}

Many learning models are developing, but certainly, not all existing models are suitable for all subjects. In theory, no single learning model is suitable for all learning processes. So the learning model should be developed following the needs and characteristics of the course. One of the learning methods that match the character of the programming language course that the purpose of solving various engineering problems is Problem-Based Learning (PBL).

$\mathrm{PBL}$ is a method of learning and training, characterized by real-world problems as a context for learners to learn critical thinking and problem-solving skills and gain knowledge. The typical characteristic of PBL that differentiates it from other learning methods is where the PBL centers on what the learners do, not what the lecturers do (Macdonald \& Isaacs, 2001). Therefore PBL is closer to the student-centered learning approach. PBL can be applied to individual and group learning processes. This method can also be applied in the classroom setting and other types of learning, such as online learning (Savin-Baden, 2006).

In the context of distance learning, PBL applications are also applied in online or network learning, both intranet and the internet. PBL provides an opportunity for learners to solve problems according to distinct ways of learning styles (visual, audio, kinesthetic).

Blended learning or hybrid courses is learning that combines online components and face-to-face components. Furthermore, it also describes all learning programs that incorporate various learning media or learning opportunities. At the most basic level, they involve thinking, reading, and mixing new information with existing knowledge.

The blended learning model with a problem-based approach must provide various basic idea form on each material to be presented. The existence of material that provides the presentation of a known fact and provides opportunities for learners to learn various issues, which then proceed with implementing problem-solving action. Furthermore, the design of the blended learning model created to provide opportunities for the evaluation directly.

The Interactive Blended Problem Based Learning (IBPBL) model is a constructivist 
learning model which is a mixture of face-to-face learning in the classroom with online learning using Moodle-based e-learning, which is an e-learning platform. There are six characteristics of this model (Sadia, I, 2014). The first is that the learning process is student-centered. The second is that the learning process takes place in small groups. The third characteristic is that the teacher acts as a facilitator or mentor. Besides, the problems presented in the learning are organized in the form, and the particular focus is a learning stimulus. The next characteristic is that new information is gained through self-directed learning. The last characteristic is that problems are the means to develop problem-solving skills (Sadia, I, 2014).

The IBPBL model was developed from the previous model of the Web-Based Interactive Blended Learning (WBIBL) model, which was also developed for the programming language course. One of the drawbacks of the previous model is that it has not yet integrated the PBL model, which is identified as the cause of the students being unable to solve problems that require critical, systematic, and innovative thinking skills to solve programming problems (Effendi \& Hendriyani, 2017a).

This model is developed to provide learners with the opportunity to develop critical thinking skills. Learners are trained to develop ways of discovering, questioning, articulating, describing, considering, and decision-making. That is, learners apply a work process to a problem situation or situation that contains problems. By implementing the model, learners apply knowledge and skills, not just receive information alone.

The differences between the models, among other blended problem-based learning models, are interactivity. Interactivity is an essential component of this model. Without interactivity, this model loses its "spirit." Interactivity is an interaction between students as learning centers with lecturers, other students, learning materials, and technology. In each syntax model, there is a guaranteed interaction of students with other learning components.

\section{Method}

This research was conducted at the Department of Electrical Engineering Faculty of Engineering, Universitas Negeri Padang (UNP). This research is Research \& Development using Borg and Gall approach.

There are ten steps to take if using the Borg \& Gall model for the development of a model/product. They are: (a) research and information collecting; (b) planning; (c) develop a preliminary form of product; (d) preliminary field testing; (e) primary product revision; (f) main field testing; (g) operational product revision; (h) operational field testing; (i) final product revision; and (j) dissemination and implementation (Gall, Gall, \& Borg, 2003). The ten-step of the Borg and Gall procedure is shown in Fig 1.

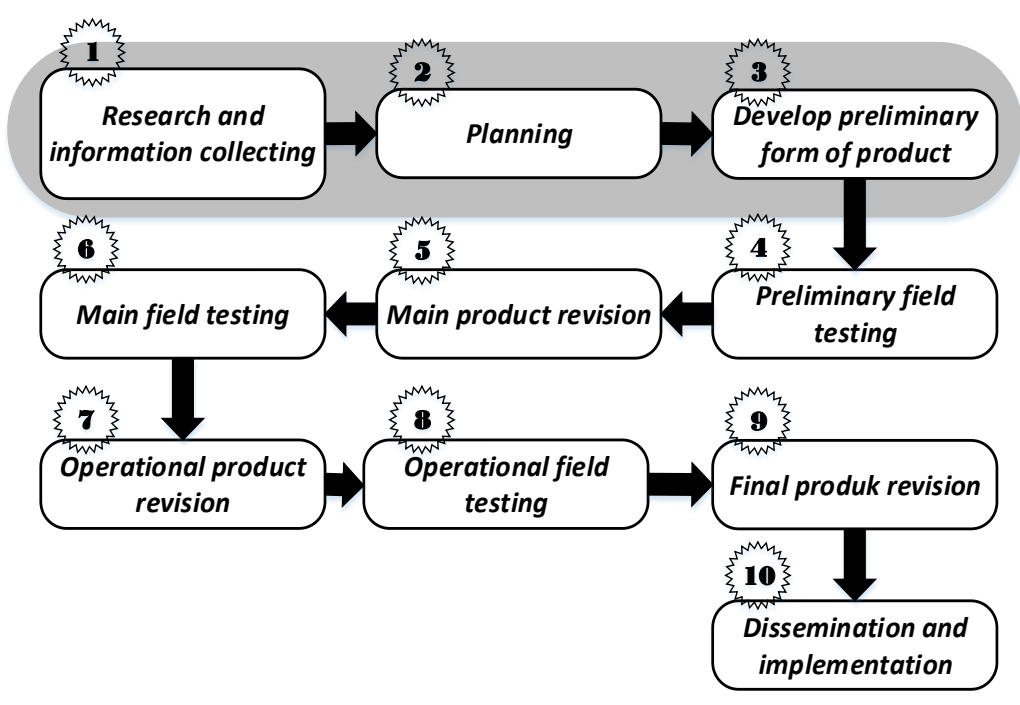

Figure 1. R \& D Procedure of Borg and Gall (Adapted from Borg \& Gall, 1983: 775) 
In the first stage, literature studies are conducted on blended learning, problem-based learning, integration of blended learning with problem-based learning, effective blended problem-based learning, relevant research, and needs analysis of blended learning at UNP.

The second stage defines product development objectives and indicators or product effectiveness criteria and small-scale feasibility tests. A feasibility test is conducted to see the availability of facilities and infrastructure that exist in UNP related to model development and research implementation.

The third stage is based on literature studies to prepare conceptual models, hypothetical models, instructional materials, and evaluation instruments. Conceptual models include philosophical foundations, theoretical framework, methodological components, and methodical/technical components. The hypothetical model is a temporary model of the IBPBL model derived from the conceptual model, which is the basis for the development of learning syntax.

\section{Results and Discussion}

\subsection{Results}

Based on the three stages of development procedures described above, the discussion in this section is divided into three stages: (a) literature review, (b) conceptual model formulation, and (c) hypothetical model formulation.

\subsection{Literature Review}

Many blended learning models have been developed. Categorization is various. As an example, NIIT categorizes blended learning into three models (Graham, 2011). The first model is skill-driven learning, which combines self-paced learning with instructor or facilitator support to develop specific knowledge and skills. The second model is attitude-driven learning, which mixes various events and delivery media to develop specific behaviors. Competency-driven learning is the last model, which blends performance support tools with knowledge management resources and mentoring to develop workplace competencies (Graham, 2011).

Meanwhile, Educators have developed six models for blended learning (Idaho Digital Learning, 2014). The face-to-face driver model is the first model that works best for diverse classrooms in which students are functioning at various levels of ability and mastery. The second model is the rotation model, which is just a variation of the learning stations model that teachers have been using for years. There is a set schedule by which students have face-toface time with their teachers and then move to online work. The next model is the flex model that relies heavily on online instructional delivery, with teachers acting as facilitators rather than as primary deliverers of instruction. The fourth model is called the online lab school model. It involves students traveling to and attending a school with total online educational delivery for entire courses. The fifth model is the self-blend model that allows coursework beyond that offered in a traditional setting in a specific school or district. Students participate in traditional classes but then enroll in courses to supplement their regular programs of study. The last model is the online driver model that is the complete opposite of a traditional face-toface instructional environment. Students work from remote locations (e.g., their homes) and receive all of their instruction via online platforms. Usually, there are opportunities to "checkin" with a course teacher and to engage in online messaging if an explanation is needed (Idaho Digital Learning, 2014).

One that distinguishes the PBL model from other learning models is the syntax. The PBL syntax consists of five stages: (a) introduction, (b) starting a new problem, (c) follow-up problems, (d) presentation performance, and (e) after the conclusion of the problem.

Previous researchers have done the integration of blended learning with PBL. Among them is research conducted by Donnelly that integrates blended learning with PBL for teacher education (Donnelly, 2006). Other researchers include Moeller, Spritzer, and Spreckelsen, who tried several interactive component combinations to see the exact blended problembased learning configuration (Moeller, Spitzer, \& Spreckelsen, 2010).

Based on a preliminary study at UNP, it was concluded that the University already has sufficient ICT facilities to implement blended learning, which includes: availability of 
bandwidth, storage devices, and fiber optic network integrated with Telkom and Indosat connecting buildings on the main campus, Moodle as its learning management system, and laboratory computers with sufficient capacity.

\subsection{Conceptual Model Formulation}

The conceptual model consists of four components, namely: (a) a philosophical foundation: pragmatism; (b) theoretical frameworks: cognitivism, behaviorism, constructivism, and connectivism; (c) methodological components: problem-based learning; and (d) technical components: problem-solving, collaboration, communication, critical thinking, creative thinking, innovation, and systematic.

\subsection{Philosophical foundation}

Miller identifies three main philosophies of vocational education that are also philosophies for education in general: essentialism, existentialism, and pragmatism (Melvin D, 2014). Furthermore, Miller defines it as follows.

Essentialism: The educator or trainer is the focal point of the learning process; mastery of subject matter is essential; development of skills through drills, repetition, conditioning, and development of desirable habits; a desire to influence the behavior of the learner.

Existentialism: The learner is the focus of the learning process; the truth is relative, and personal growth and development are critical to the process.

Pragmatism: The educator and learner are both critical to the learning process; reality or real-world situations are stressed; context and experience are essential, and the educator is progressive and open to new ideas.

The philosophy foundation used in the IBPBL model is Pragmatism. Pragmatism considers thinking as an instrument or tool for prediction, problem-solving and action, and rejects the idea that the function of thought is to describe, represent, or reflect reality.

\subsection{Theoretical framework}

There are four theoretical frameworks used in the development of the IBPBL model: (a) behaviorism paradigm, (b) cognitivism paradigm, (c) constructivism paradigm, and (d) connectivism.

In the behaviorist paradigm, learning is defined as a behavioral change that can be facilitated through strengthening specific stimuli and responses (Naismith, Lonsdale, Vavoula, \& Sharples, 2004), and students are considered reactive to conditions in their environment (Ertmer \& Newby, 1993). It may mean that the lecturer encourages student-specific behavior outcomes through a set of defined learning objectives ("Learning theories: A to Z," 2003).

The paradigm of cognitivism focuses on the student's mental activity. Because of its emphasis on mental structure, this theory is considered more appropriate to explain complex forms of learning, such as reasoning, problem-solving, and information processing. In cognitive learning, knowledge acquisition is described as a mental activity that requires coding and internal organization by students so that students are considered as an active participant in the learning process (Ertmer \& Newby, 1993). This paradigm believes that learning is the result of organizing and processing information effectively (Jordan, Carlile, \& Stack, 2008). Therefore the information should be organized so that learners can connect new information with existing information in meaningful ways.

Constructivism puts learners in an open learning environment where they build their meaning from knowledge and content. Environmental factors are considered necessary because the synergy between students and the environment creates knowledge. In constructivist learning, it is essential to learn to occur in realistic settings, and the learning task must be relevant to the learner (Ertmer \& Newby, 1993). So the constructivist learning environment must provide a rich experience that encourages students to learn. The goal is to teach a great concept by using student activity, social interaction, and authentic assessment (Schunk, 2012).

Connectivism was introduced by George Siemens, which is a theory of learning in the digital age. This theory aims to provide insight into the learning skills and tasks required in the 
digital age. This theory argues that learning is no longer an internal, individualistic activity, and that the way people work and function is changed when new tools are exploited (Siemens, 2005). This approach emphasizes the importance of information and connects it to the right people, so efficient navigation and information filtering is essential.

\subsection{Methodological components}

The methodological component that is used in the IBPBL model is problem-based learning. Problem-based learning is designed in a learning procedure that begins with a problem and uses the instructor as a metacognitive trainer. The learning process begins once students are exposed to the real problem structure, so they know why they should study the material. After that, they must gather information to be analyzed and use that information in solving the problems encountered.

Through problem-based learning, students learn how to use interactive processes to evaluate what they know, identify what they need to know, gather information, and collaborate in evaluating a hypothesis based on data collected. While the lecturer acts as tutor and facilitator in digging and finding the hypothesis and take a conclusion.

\subsection{Methodical/technical components}

21st-century skills are a set of skills, abilities, and dispositions that are needed for success in the 21 st-century society and workplace. Many of these skills are related to deeper learning, based on mastering skills such as analytic reasoning, complex problem solving, and teamwork. These skills differ from traditional academic skills because their basic knowledge is not knowledge-based. Some of these skills are critical thinking, creative thinking, communication, and collaboration.

PBL provides opportunities for learners in the development of critical thinking skills. Learners are trained to develop ways of discovery, questioning, articulating, describing, considering, and decision-making. That is, learners apply a work process to a problem situation or situation that contains problems.

The conceptual model of IBPBL that is discussed above is shown in Fig 2.



Figure 2. The conceptual model of IBPBL 


\subsection{Hypothetical Model Formulation}

The hypothetical model is based on the ability of students to solve problems critically, creatively, collaboratively, systematically by utilizing various advantages possessed by faceto-face and online learning in a programming language course in Electrical Engineering. The hypothetical model of IBPBL is shown in Fig 3. Model validation is performed using expert judgment. Expert judgment assesses the IBPBL model in aspects of the adequacy of components, content, and ease of implementation. Based on these three aspects, the model is valid.

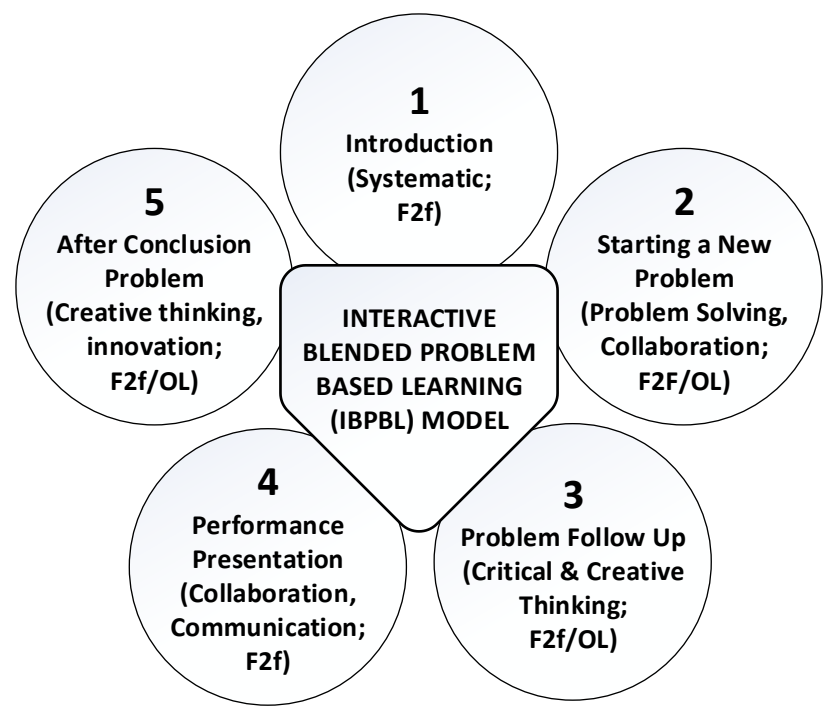

Figure 3. The hypothetical model of IBPBL

This model has been applied on a small scale in the course of Programming Languages in the Department of the Electrical Engineering State University of Padang. Learning is done online and face-to-face in the classroom. At the first meeting in the classroom, the learning objectives are explained. Besides, students are given motivation and apperception on the topic to be discussed. Students are also given knowledge on how to solve problems systematically. Then the students are given a case study related to the topic being discussed. At this stage, students demonstrate the ability to solve problems and the ability to collaborate with classmates in search of answers to a given problem. This stage is done face to face in class and online. In the online session, students can collaborate and work together using the discussion forums provided. In the next stage, the initial work of the students is discussed in the classroom to find the best problem-solving alternatives. Furthermore, students in groups presented their findings. After that, the student makes a summary of the topic discussed individually and upload his work in the space provided. It continues for every topic that exists. The design of the online model can be seen in Fig 4. 


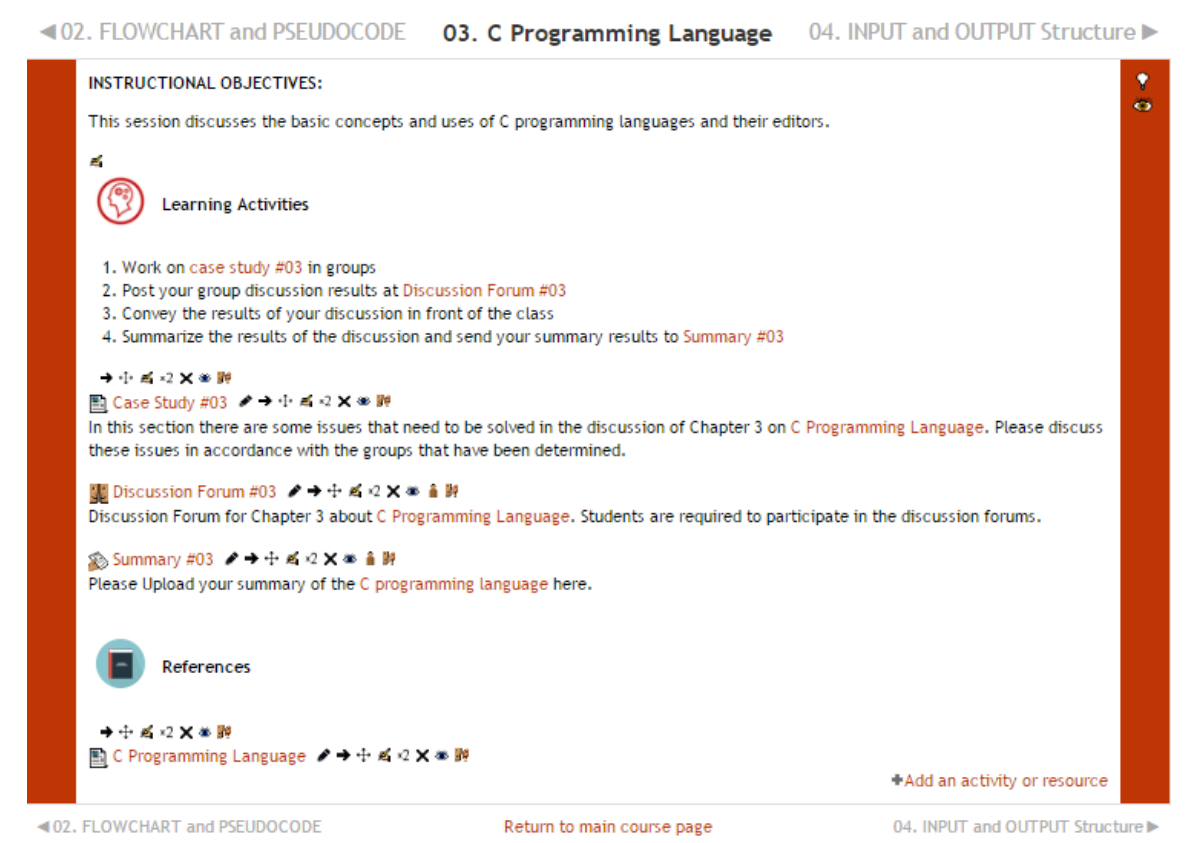

Figure 4. The Design of Online Session of IBPBL Model

\subsection{Discussions}

Lots of blended learning models have been developed, especially in Universitas Negeri Padang. Some of them are Interactive Blended Learning (IBL) model that considers locus control and student learning styles (Mawardi Effendi, Effendi, \& Effendi, 2017). This model has been tested in several courses and has been proven effective in improving student learning outcomes. Especially for programming subject has also been developed model of Web-Based Interactive Blended Learning (WBIBL) which has also been tested its effectiveness but there are still shortcomings that are not yet developed the ability of students in solving programming problems presented in the form of program code problems (Effendi \& Hendriyani, 2017b).

The IBPBL model solves the problem, whereas this model overcomes the obstacle in terms of growing soft skills of students, especially in solving a programming problem. The collaboration between face-to-face learning in the classroom and online learning with the syntax of problem-based learning is to address this issue. Some other skills that are wanted to grow by learning to use this model are the ability in communication, collaboration, creative thinking, critical thinking, systematic, and innovative. Those skills are necessary for students in solving problems in the course of programming languages.

This model has not considered the student learning style, which is also an essential factor to consider in the learning process (Drissi \& Amirat, 2016). In a further development, the IBPBL model will consider the learning style as one component of the model so that the model can be adaptive to the characteristics of diverse students.

\section{Conclusion}

Based on the literature study, an interactive blended learning model with the syntax of problem-based learning has been developed with the name of Interactive Blended Problem Based Learning which is abbreviated as IBPBL with the following model components: (1) a philosophical foundation: pragmatism; (2) theoretical frameworks: cognitivism, behaviorism, constructivism, and connectivism; (3) methodological component: problem-based learning; and (4) methodical/technical components: problem-solving, collaboration, critical thinking, innovative, creative, and systematic. The hypothetical model is based on the ability of students to solve problems critically, creatively, collaboratively, systematically by utilizing the advantages possessed by face-to-face and online learning in a programming language course. 


\section{References}

Donnelly, R. (2006). Blended problem-based learning for teacher education: Lessons learnt. Learning, Media and Technology. https://doi.org/10.1080/17439880600756621

Drissi, S., \& Amirat, A. (2016). An experimental study to evaluate learning style personalisation in web-based adaptive e-learning systems. International Journal of Innovation and Learning. https://doi.org/10.1504//JIL.2016.076669

Effendi, H., \& Hendriyani, Y. (2017a). The Develoment Of Interactive Blended Problem Based Learning Model For Programming Subject. 4th ICTVET, 277-282. https://doi.org/10.31227/OSF.IO/VFMNY

Effendi, H., \& Hendriyani, Y. (2017b). The effectiveness of web-based interactive blended learning model in programming language courses. In A. Setiawan, M. B. A. Alias, A. Gafar, \& T. Aryanti (Eds.), Regionalization and Harmonization in TVET: Proceedings of the 4th UPI International Conference on Technical and Vocational Education and Training (TVET 2016), November 15-16, 2016, Bandung, Indonesia (pp. 175-178). https://doi.org/110.1201/9781315166568-42

Ertmer, P. A., \& Newby, T. J. (1993). Behaviorism, Cognitivism, Constructivism: Comparing Critical Features from an Instructional Design Perspective. Performance Improvement Quarterly. https://doi.org/10.1111/j.1937-8327.1993.tb00605.x

Gall, M. D., Gall, J. P., \& Borg, W. R. (2003). Educational Research: An Introduction. Educational Research: An Introduction. Retrieved from http://psycnet.apa.org/psycinfo/1996-97171-000

Graham, C. R. (2011). Blended Learning Models. In Encyclopedia of Information Science and Technology, Second Edition. https://doi.org/10.4018/978-1-60566-026-4.ch063

Idaho Digital Learning. (2014). 6 Models of Blended Learning. 6 Models of Blended Learning. Jordan, A., Carlile, O., \& Stack, A. (2008). Approaches to learning: A guide for teachers. In British Journal of Educational Technology.

Learning theories: A to Z. (2003). Choice Reviews Online. https://doi.org/10.5860/choice.410068

Macdonald, D., \& Isaacs, G. (2001). Developing a professional identity through problem-based learning. Teaching Education. https://doi.org/10.1080/10476210120096579

Mawardi Effendi, Z., Effendi, H., \& Effendi, H. (2017). The role of locus control and learning styles in the development of the blended learning model at PSU. International Journal of GEOMATE, 13(7), 75-80. https://doi.org/10.21660/2017.37.TVET025

Melvin D, M. (2014). Principles and a Philosophy for Vocational Education. Igarss 2014. https://doi.org/10.1007/s13398-014-0173-7.2

Moeller, S., Spitzer, K., \& Spreckelsen, C. (2010). How to configure blended problem based learning results of a randomized trial. Medical Teacher. https://doi.org/10.3109/0142159X.2010.490860

Naismith, L., Lonsdale, P., Vavoula, G., \& Sharples, M. (2004). Report 11: literature Review in mobile technologies and learning. A report for NESTA Futurelab. University of Birmingham. Retrieved February.

Sadia, I, W. (2014). Model-model pembelajaran sains konstruktivistik. Yogyakarta: Graha Ilmu.

Savin-Baden, M. (2006). The challenge of using problem-based learning online. In Problembased Learning Online. https://doi.org/10.4324/9780203095959

Schunk, D. H. (2012). Learning theories: An educational perspective. In Reading.

Siemens, G. (2005). Connectivism: A learning theory for the digital age. International Journal of Instructional Technology and Distance Learning. 